\title{
Physical modeling of the long-term behavior of integral abutment bridge backfill reinforced with tire-rubber
}

\author{
Mehdi Zadehmohamad ${ }^{1}$, Jafar Bolouri Bazaz ${ }^{2^{*}}$, Ramin Riahipour ${ }^{3}$ and Visar Farhangi ${ }^{4}$
}

\author{
${ }^{*}$ Correspondence: \\ bolouri@ut.ac.ir \\ ${ }^{2}$ Civil Engineering \\ Department, Associate \\ Professor, Ferdowsi University \\ of Mashhad, Mashhad, Iran \\ Full list of author information \\ is available at the end of the \\ article
}

\begin{abstract}
The primary objective of this study is to investigate the benefits of adding tire rubber as an inclusion to backfill behind integral bridge abutments. In this respect, four physical model tests that enable cyclic loading of the backfill-abutment are conducted and evaluated. Each test consisted of 120 load cycles, and both the horizontal force applied to the top of the abutment wall and the pressures along the wall-backfill interface is measured. The primary variable in this study is the tire rubber content in the backfill soil behind the abutment. Results show adding tire rubber to the backfill would be beneficial for both pressure and settlement behind the abutment. According to results, adding tire rubber to soil decreases the equivalent peak lateral soil coefficient ( $\left.K_{\text {eq-peak }}\right)$ up to $55 \%$ and earth pressure coefficient $\left(K^{*}\right)$ at upper parts of the abutment up to $59 \%$. Moreover, the settlements of the soil behind the wall are decreased up to $60 \%$.
\end{abstract}

Keywords: Integral Bridge, Physical modeling, Tire-rubber, Pressure, Settlement

\section{Introduction}

There are many efforts and researches to attenuate pavement and bridge problems every year $[12,16,36,3,8,17,19]$. One of the most problematic issues with conventional bridges is the malfunctioning of sliding bridges. The integral bridge concept eliminates the problem with bearings and related issues; however, there would be problems in backfill soil. The abutments of integral bridges are forced to move away from or toward the backfill soil when the deck length changes due to temperature variation (Fig. 1).

Thus the bridge superstructure, foundation pile, abutments, and backfill soil are all subject to cyclic loading. Understanding their interactions is essential for the effective design and performance of integral bridges [2, 9, 35, 63]. In this respect, engineers face several challenges when designing integral bridge abutments (IABs) because rational and validated procedures are not yet available to evaluate the magnitude and distribution of the pressures imposed by the abutments' displacement, motivated by the thermal deformation of the deck. Daily and seasonal cycles of expansion/contraction of the bridge deck may result in several problems, such as a significant increase in earth pressure behind the abutment $[7,20,29,43,51]$. The nature of the problem author(s) and the source, provide a link to the Creative Commons licence, and indicate if changes were made. The images or other third party material in this article are included in the article's Creative Commons licence, unless indicated otherwise in a credit line to the material. If material is not included in the article's Creative Commons licence and your intended use is not permitted by statutory regulation or exceeds the permitted use, you will need to obtain permission directly from the copyright holder. To view a copy of this licence, visit http:// creativecommons.org/licenses/by/4.0/. 


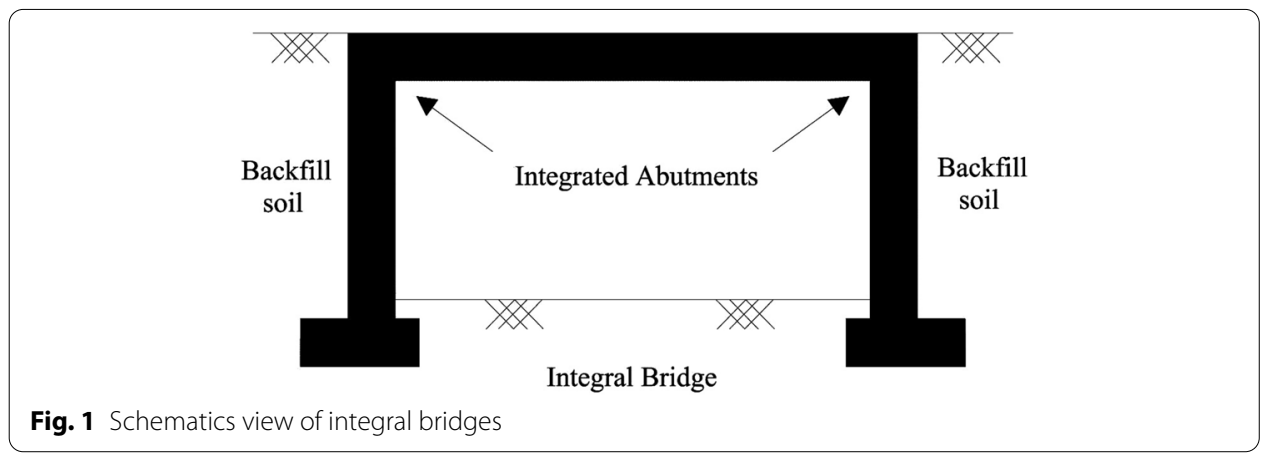

is even more complicated due to the substantial difference between the soil's stiffness and the structural elements, the soil's nonlinear response, and the complex threedimensional geometries of IABs [28].

Another significant consequence is the deformation of soil adjacent to the abutment. Such settlement occurs because of soil slumping in backfill soil. The real extent of the settlement's impacts depends on whether an approach slab is constructed as an integral part of the bridge. If there is a slab, initially, it will span over the void created underneath [40]. However, with time and traffic, the slab will likely fail due to flexural stresses [41]. Since the settlement tends to develop and become problematic soon after an IAB is placed into service, this subject has received much more interest than the development of the lateral earth pressure in recent years $[5,18,55]$. For mitigating both problems, the relative movement between ground and bridge should be made compatible.

A purely structural approach is to shorten the height of each abutment remarkably. Even if the abutment's lateral earth pressures still increase over time, the flexural stress and total resultant force generated by the abutment will be significantly lower because of the abutment's slenderness, and its effective top-displacement is considerably reduced [27].

One of the most effective ways to decrease geotechnical problems is using reinforcement in soils $[4,23,34,45,52,65]$. The use of reinforced soil is an effective way to reduce the horizontal pressure on the abutment and the backfill's subsequent settlement $[39,47]$. This reinforcement can be obtained with geosynthetics guaranteeing a significant tensile strength increase in backfill. The application of geosynthetics is studied by Tatsuoka et al. [53], which leads to the construction of geosyntheticreinforced abutments supporting integral bridges for high-speed train lines in Japan after the 2011's tsunami $[55,56]$. In this case, the backfill soil is reinforced with geosynthetics and cement grouting. Additionally, Yonezawa et al. [61] reported that this type of bridge showed good performances during long-term service and earthquakes. More recently, Zadehmohamad and Bolouri Bazaz [64] concluded that using several layers of geocell for reinforcement of the abutment could result in less pressure and settlement.

An interesting alternative of reinforced backfill is elastic compressible inclusions, capable of mitigating the soil pressure increase behind the abutment during deck expansion. In general, a compressible inclusion is any material that, when installed 
in the ground (in any application, not just IABs) has a remarkably more compressible behavior than the soil matrix under a given magnitude of stress. This differential deformation will generally result in an overall reduction in the abutment's pressure and settlement [25-27].

Hoppe [24] studied Expanded Poly Styrene (EPS) geofoam application as a compressible material located behind the abutments. This solution allowed for a significant reduction in lateral earth pressures on the back wall, which lead to more tolerable settlements of the backfill. It is also reported that the Geofoam absorbed vertical stresses from the overlying granular fill and approach slab [24].

There are increasing efforts to use recycled materials in civil engineering applications [21, 42, 66]. Tire Derived Aggregates (TDA) is a recycled compressible material that has been used in civil engineering applications for several years. In geotechnical engineering, TDA is used in lightweight fills, backfill materials, highway embankments, soil reinforcement, and soil-retaining walls [30, 37, 44, 58, 59, 62, 22, 49, 46, 48, 50]. Humphrey et al. [32] conducted large-scale direct shear tests on tire-soil admixtures and reported that tire shreds are useful in constructing lightweight embankments over soft ground. Ahmed and Lovell [1], and Edil and Bosscher [14] reported that sand could also be reinforced using tire chips. According to those studies, tire shreds' addition increased the sand shear strength levels substantially, concluding that $30 \%$ of tire shred is an optimum ratio by volume.

Short-term compressibility of TDA and TDA-sand admixtures has been investigated using full-scale embankment fills [11,37] and laboratory-scale tests [31, 60]. These studies revealed that TDA materials exhibit a high degree of compressibility upon initial loading, especially at low-stress levels (below $100 \mathrm{kPa}$ ). According to these studies, as the stress level increased, the TDA material became less deformable, typical of a highly nonlinear material.

Some researchers also developed laboratory studies on the long-term compressibility of TDA materials and TDA sand admixtures $[32,60]$. The researchers generally report that the deformations resulting from long-term compression may finally govern the long-term performance and serviceability of TDA structures, especially when thick layers of TDA are used in geotechnical systems having long service lives. The experiments also show that long-term compression of TDA is independent of applied stress and tire particle size. However, the long-term behavior of TDA soil mixtures behind integral bridge abutment under cyclic loading is little known by today.

In areas where the underlying ground is compressible or soft, tire shreds, with their lower unit weight, would apply smaller vertical stress than conventional granular backfills, resulting in lower settlement and increased global stability [33, 57]. According to these studies, the horizontal stress on a retaining wall also would be lower than conventional backfill, leading to a less expensive retaining wall design. Moreover, tire shreds are draining materials and do not contribute to the excess pore pressure generation, capable of preventing stability problems when the backfill is saturated. Based on the results of a full-scale field test, Humphrey and Eaton [30] reported that the use of tire shreds could also reduce the depth of frost penetration. All these advantages associated with tire shreds can translate into economic benefits, as highlighted by Cecich et al. [13]. According to this study, TDAs, which typically show a unit weight of approximately one-third 
of the typical soil backfills, can result in smaller retaining walls, smaller foundations, and less steel reinforcement.

This study's main objective is to evaluate and quantify the benefits of adding tire rubber to the backfill of the integral bridge abutment. The benefits are measured in terms of backfill pressure on abutment and settlements. For this reason, four small scale physical models are tested and evaluated. The models are subjected to 120 cyclic movements, which resemble the movement of the integral bridge's abutment during 120 years. The primary variable in this study is tire rubber content in the soil mixture behind the abutment.

\section{Materials and method}

The following sections describe the laboratory set-up of the tire-sand mixed backfill models for an integral bridge. The experiments are designed to investigate the lateral soil pressures and settlements developed on the back of a stiff vertical abutment of height $\mathrm{H}$, rotate over its base axis by displacements $\delta$, applied at the bridge deck level. A total of four physical model tests are performed, with different TDA contents on the sandbased backfill. In each test, 120 loading cycles are applied to the wall by a motor. The lateral load at the top of the wall and the pressures throughout the wall height are then measured.

\section{Equipment}

A model box is constructed using a steel frame with dimensions $190 \times 85 \times 40 \mathrm{~cm}$ (Fig. 2). The side walls are made with $10 \mathrm{~mm}$ glass panels to minimize the friction between the sand and the sidewall and allow the observation of both the surface settlements and shear bands on the soil. The box's top walls (one of them simulating the abutment) are made from polytetrafluoroethylene (PTFE) Teflon to ensure the required strength. This wall is allowed to rotate over a hinge installed $10 \mathrm{~cm}$ from the bottom of the box. It is also stiffened with steel frames to ensure rigid behaviour.

In order to measure wall displacements, two Linear Variable Differential Transformer (LVDT) are installed at the top and middle of the abutment, as well as six pressure cells (PC) (Fig. 3), to measure the soil pressure behind the wall during rotation. These pressure cells are installed at $10,20,30,40,50$, and $60 \mathrm{~cm}$ above the hinge.

The cyclic displacement of the wall towards and away from the soil is achieved by an actuator equipped with a $50 \mathrm{kN}$ load cell to measure the applied lateral forces. The actuator, which could move the top of the wall at different speeds, is hung from a steel plate and connected to the back of the abutment through a spherical bearing hinge to ensure that no bending moments would be applied to the wall (Fig. 4). The amplitude of displacement at the top of the wall is $4.2 \mathrm{~mm}$. Displacements at the top of the wall occur in about $60 \mathrm{~s}$, which means the velocity of displacement is about $0.07 \mathrm{~mm} / \mathrm{s}$ (static loading condition).

Besides, PTFE strips are used in the abutment's side faces to prevent soil loss during cyclic loading and minimize the friction between the abutment wall and the glass panels. Due to the wall's smoothed face, the friction between the walls and the sand is very low. The acquisition system log data with a $1 \mathrm{~Hz}$ logging frequency for all instruments in the tests. The settlements after each cycle are obtained from photographs by getting images 


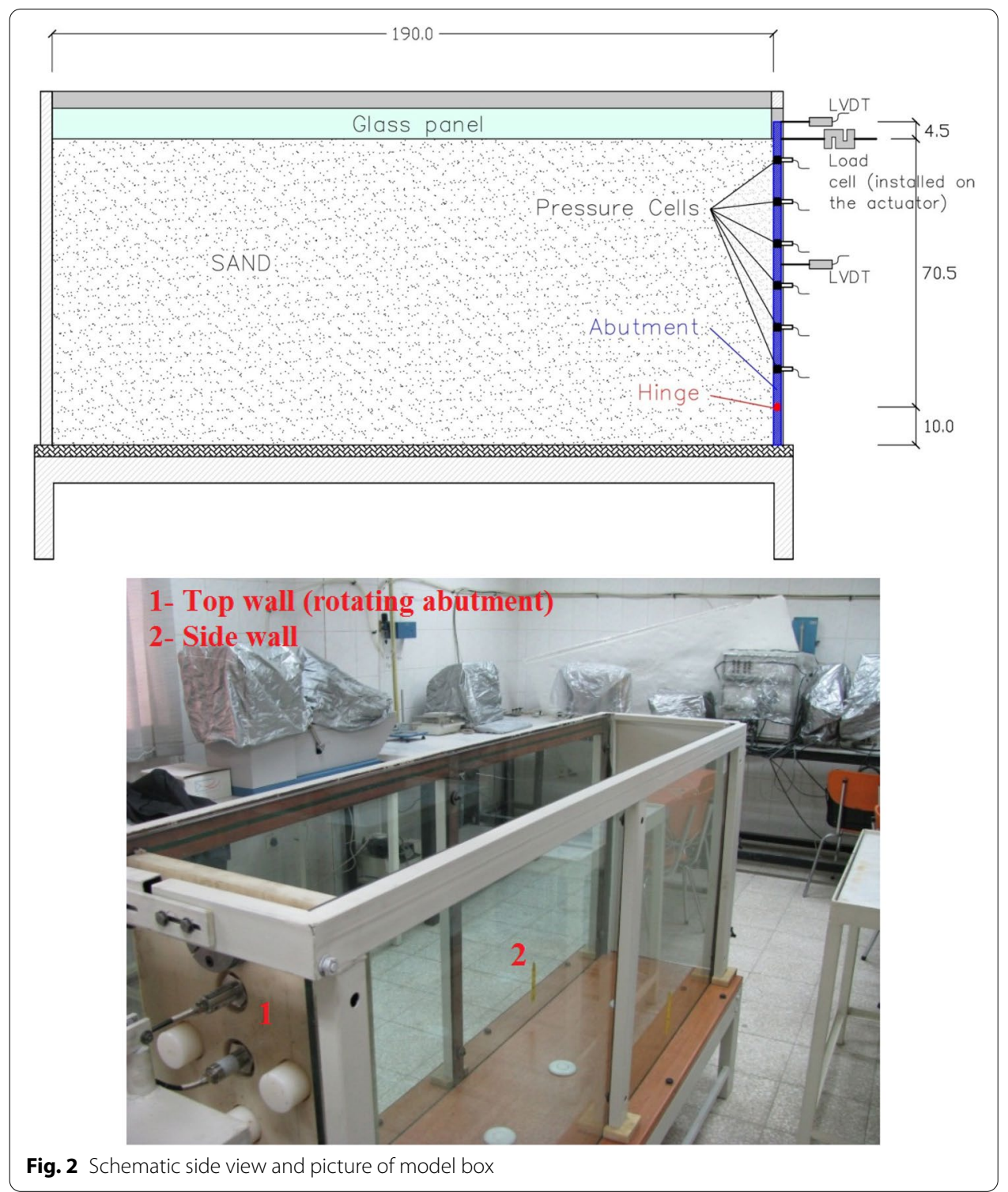

from the surface. Also, active shear zones are observable with the help of colored sand layers.

\section{Materials}

In this study, Firoozkooh NO. 161 sand, a well-known material at Iranian research centers and universities, is used. The particle size distribution and other characteristics of this sand, together with Toyoura and Sengenyama sand (for reference), are presented in Table 1 and Fig. 5 [6]. In the present study, the sand beds behind the wall are prepared with a relative density of $85 \%$ (i.e. in a dense condition).

The tire rubber used in these tests is obtained from the municipal recycling division of the Mashhad City in Iran. The initial size range of the rubber particles is between 2 and $5 \mathrm{~mm}$ (Fig. 6). 


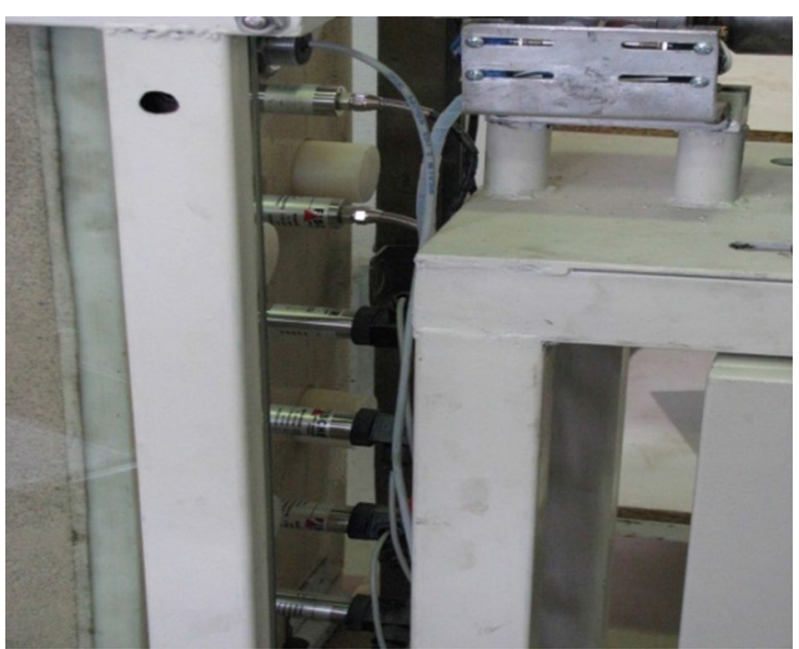

Fig. 3 Detail of the installation of the pressure cells

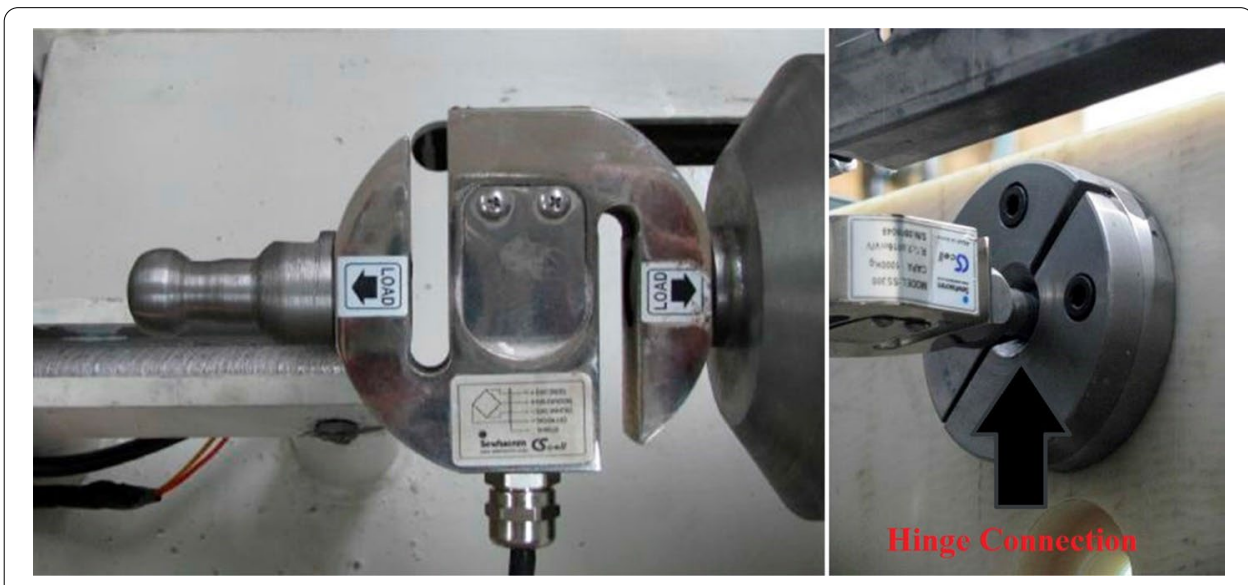

Fig. 4 View of the load cell and the hinge connection to the wall

Table 1 Characteristics of Firoozkooh 161 sand compared with Toyoura and Sengenyama sand

\begin{tabular}{lllllllll}
\hline Sand & $\begin{array}{l}\mathbf{D}_{\mathbf{1 0}} \\
(\mathbf{m m})\end{array}$ & $\begin{array}{l}\mathbf{D}_{\mathbf{3 0}} \\
(\mathbf{m m})\end{array}$ & $\begin{array}{l}\mathbf{D}_{\mathbf{6 0}} \\
(\mathbf{m m})\end{array}$ & $\mathbf{C}_{\mathbf{u}}$ & $\mathbf{C}_{\mathbf{c}}$ & $\mathbf{e}_{\max }$ & $\mathbf{e}_{\min }$ & $\mathbf{G}_{\mathbf{s}}$ \\
\hline Firuzkooh N0.161 & 0.16 & 0.21 & 0.28 & 1.87 & 0.88 & 0.943 & 0.548 & 2.65 \\
Toyoura & 0.15 & 0.19 & 0.20 & 1.54 & 1.25 & 0.977 & 0.597 & 2.65 \\
Sengenyama & 0.15 & 0.21 & 0.28 & 2.15 & 1.21 & 0.911 & 0.616 & 2.72 \\
\hline
\end{tabular}

\section{Test preparation}

A new portable curtain sand pluviator is designed and developed (Fig. 7) to prepare the sand beds inside the model box, with a given relative density (RD). The system consisted of a hopper, with a $20 \mathrm{~kg}$ capacity, installed on a rigid modular frame. The frame is then connected to a modular wheeled frame that could move the hopper back and forth, longitudinally, using a belt on a pair of rails. The modular frame allowed the sand 


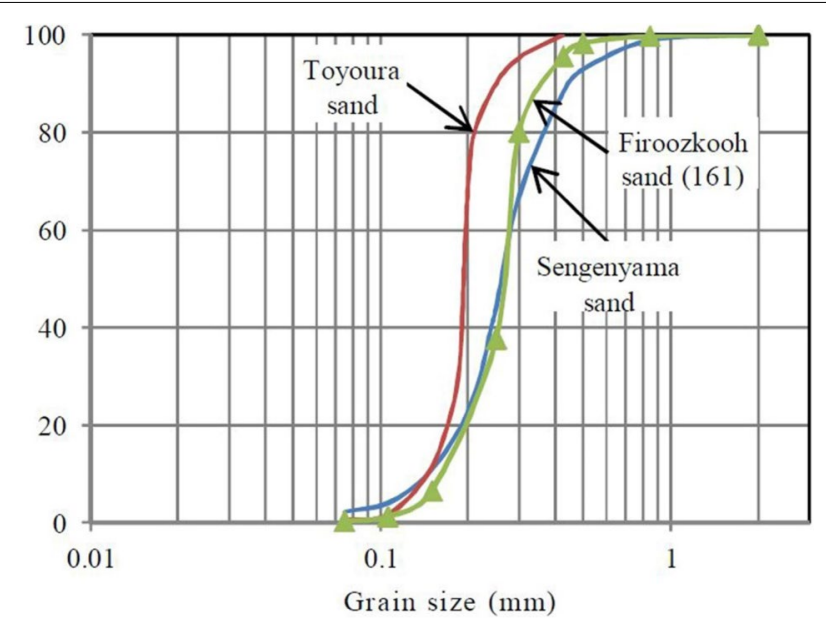

Fig. 5 Particle size distribution of Firoozkooh 161 sand compared with Toyoura and Sengenyama sand
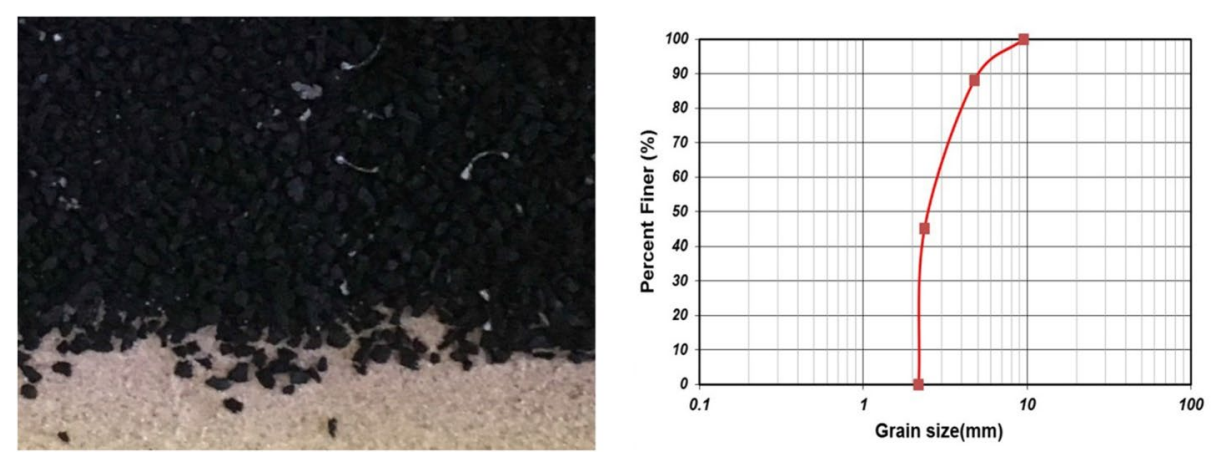

Fig. 6 General aspect and particle size distribution of the tire rubber particles

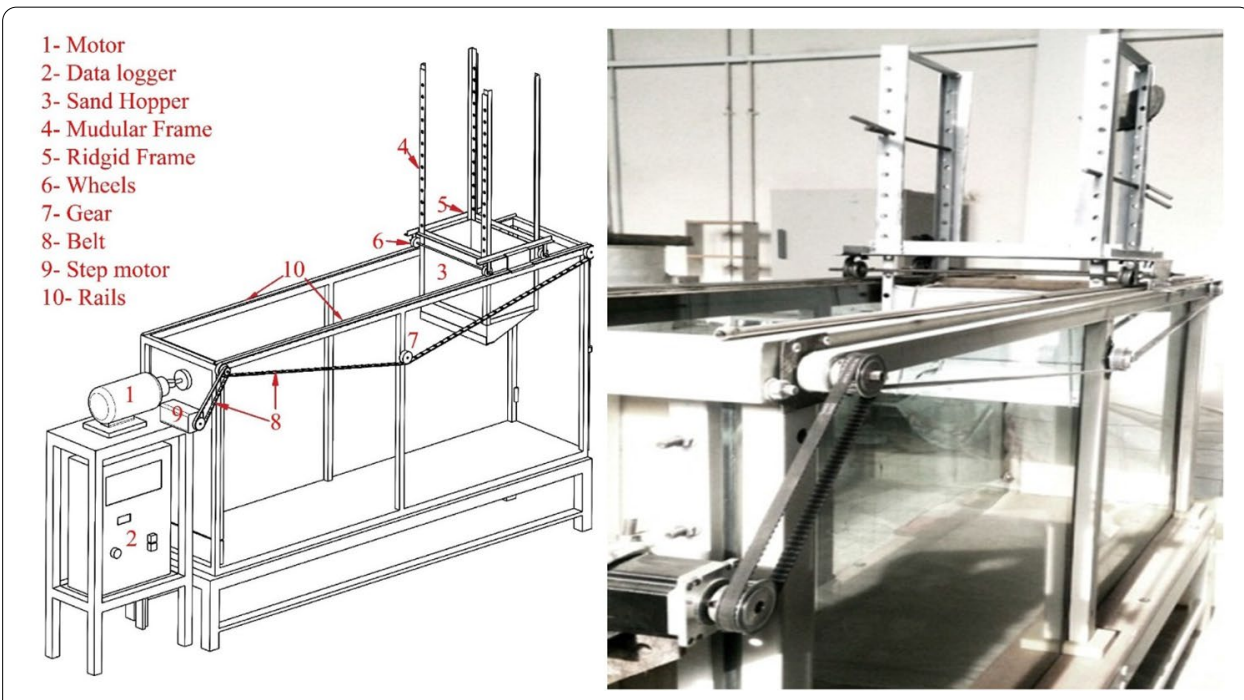

Fig. 7 Schematic view and picture of the sand pluviation system mounted on the model box 
drop height to be adjusted and thus keep it constant as the sand surface increased. The belt is connected to a series of gearwheels powered by a stepping motor. The motion is reversed automatically when a certain limit is reached. The hopper's velocity could be controlled in the range of $0.4-4 \mathrm{~cm} / \mathrm{s}$ [10].

The sand exits the hopper through an aperture on the bottom, allowing it to pour it in thin horizontal layers in the form of a curtain. The development of slip lines and active shear zones in the soil mass is observed using colored sand layers at $10 \mathrm{~cm}$ intervals.

The tire rubber is poured in layers after each corresponding sand layer is poured (Fig. 8). A specific volume of tire rubber is initially spread on a constant width ' $D$ ' with a thickness approximately even. In the second stage, the tire rubber is gently pushed against the underlying sand. Lastly, two sand layers (made from a back and forth movement of the curtain pluviator) are poured over the tire layer before another tire rubber layer has been prepared. The rubber weight per layer is adjusted as a function of the mixture content that is intended for each test. After construction, the exact percentage of tire rubber content in the reinforced zone is obtained by dividing the rubber's total volume by the mixed area volume.

\section{Test program}

A total of four physical models are constructed and tested in this study to evaluate the effect of the rubber content in the mixed zone. It is considered that a reasonable design basis for an integral bridge abutment with a 120-year lifespan would involve the application of 120 cyclic loadings, at an amplitude consistent with the differential temperature acting on the deck between the coldest winter night and the warmest summer day. Therefore, the normalized displacement applied to the top of the wall is selected to be

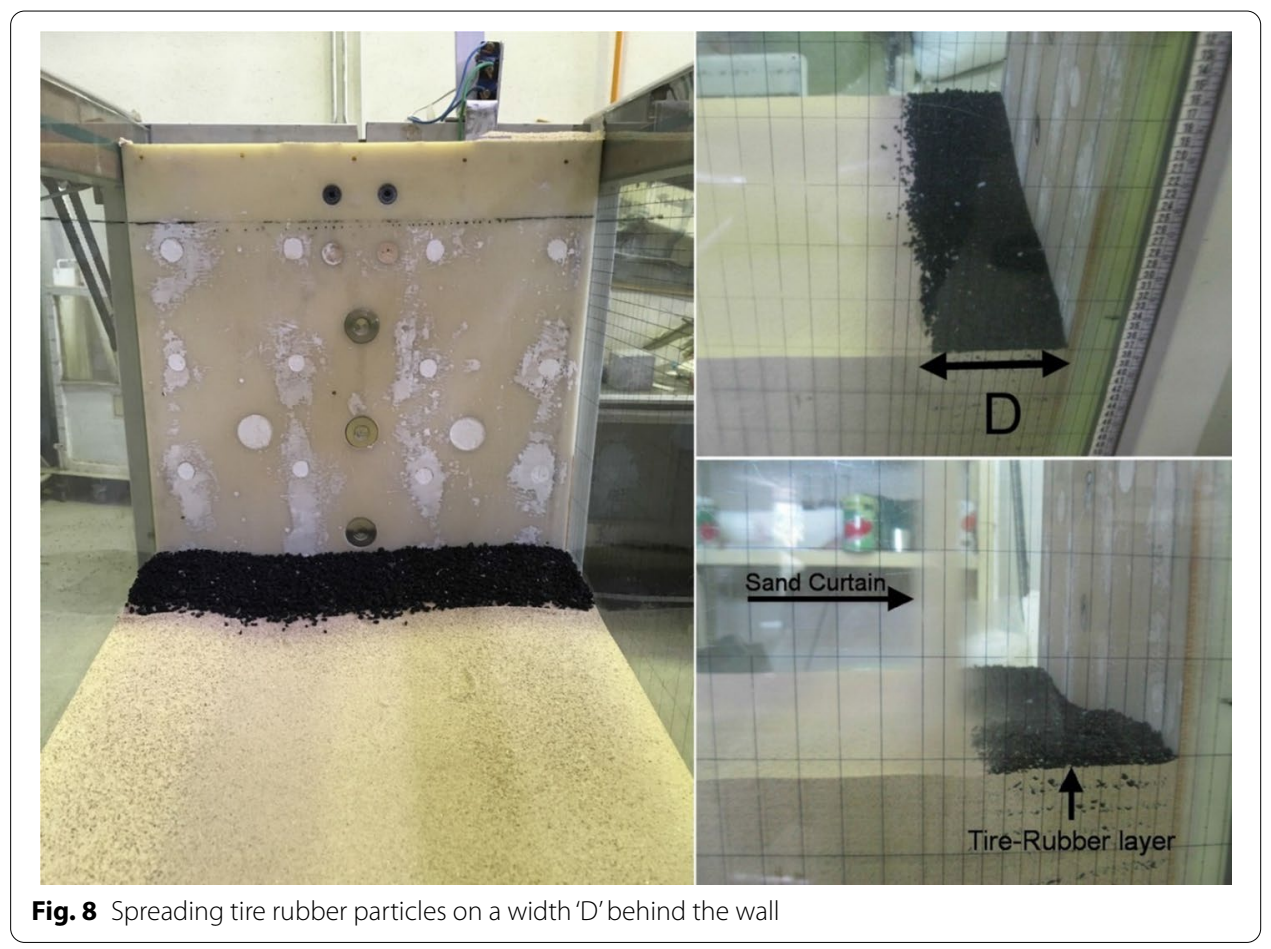




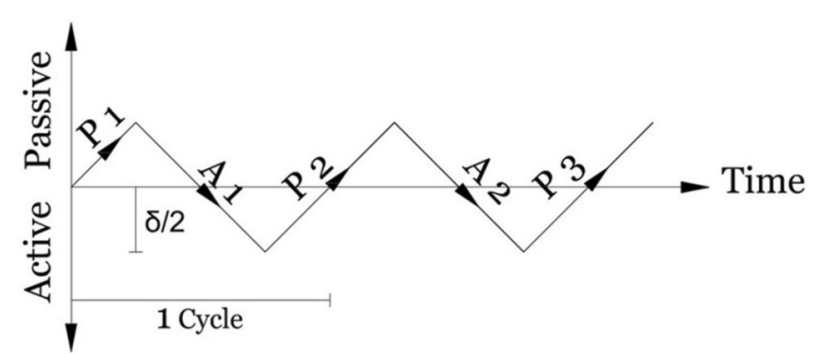

Fig. 9 Characterization of the applied displacement cycles to the top of the wall

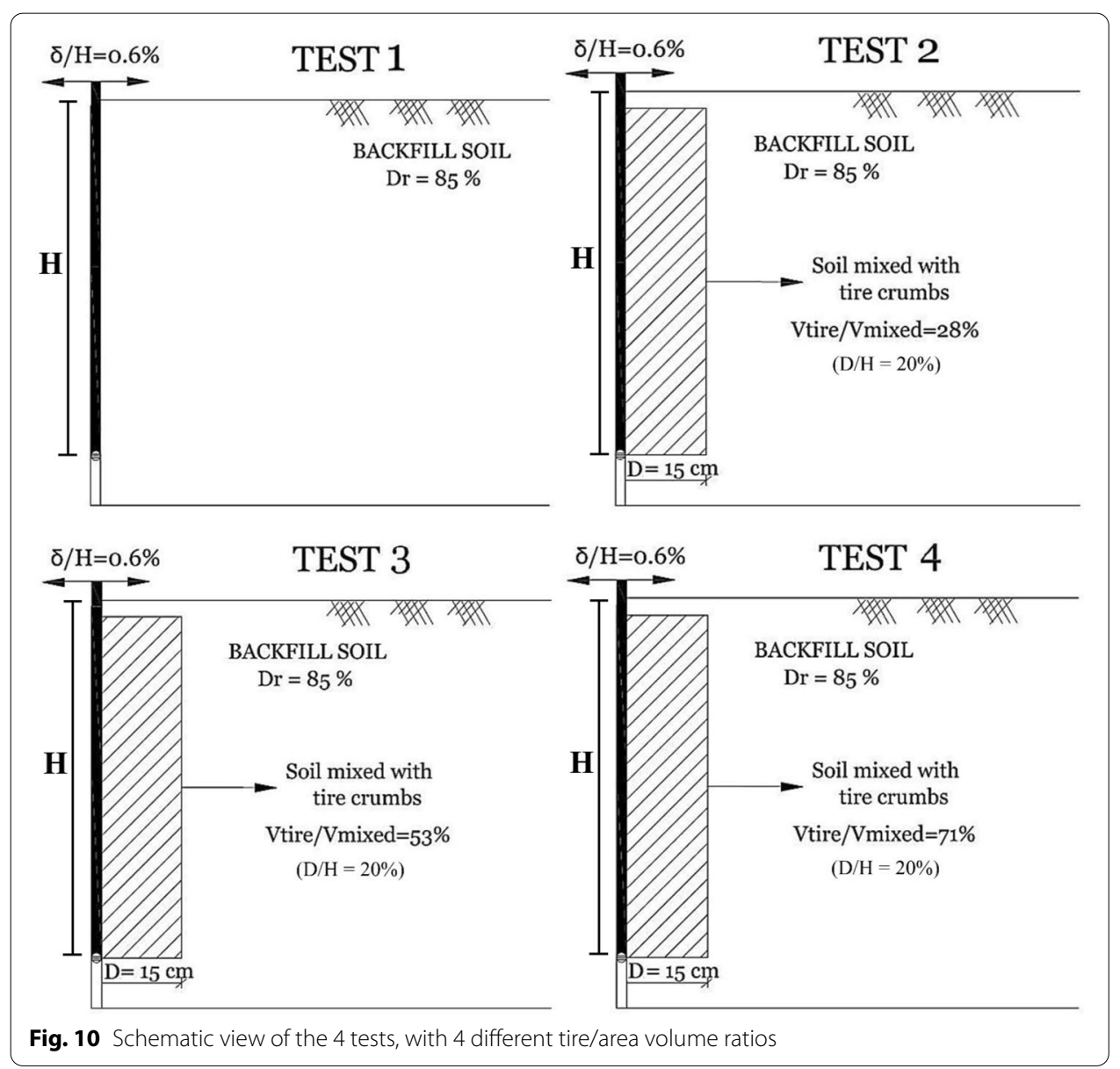

$\delta / \mathrm{H}=0.6 \%$ ( $\delta$ is the amplitude of displacement, and $\mathrm{H}$ is the height of the backfill soil above the hinge). The $\delta / \mathrm{H}$ value is obtained by considering different amplitudes presented in previous researches $[18,38,54,63,64]$. For each test, the first cycle started with a passive-side pressure (Fig. 9). A total of 4 tire rubber contents (including the $0 \%$ value used for Test 1 to establish a reference) are tested and compared (Fig. 10). The rubber contents are indicated by $V_{\text {tire, }}$ which is the net volume of tire rubbers obtained from its weight and specific weight, and $V_{\text {mixed, }}$ which is the volume of the mixed area behind the wall obtained from the multiplication of height, width, and length of the mixed area. 


\section{Lateral earth pressure coefficient}

Lateral earth pressure coefficient is the ratio between lateral and vertical pressure behind the wall. This coefficient is defined in geotechnical engineering problems based on the relative wall-backfill movement. For classical geotechnical problems, there are three predefined coefficients for backfill soil. When the soil and wall have no relative movement, the lateral coefficient would be $K_{0}$, and the condition is called at rest. When the wall pushes the soil, the condition is called passive, and the lateral coefficient would be $K_{p}$, and the case that the soil pushes the wall is the active condition, and the lateral coefficient would be $K_{\mathrm{a}}$. It should be noted that the active and passive forces on the wall are theoretically and experimentally the lower and upper limit of the possible forces on the wall when the wall is moving back and forth to the soil. For the abutment of integral bridges, the maximum force is lower than the passive condition and higher than at rest condition because of the lower magnitude of displacement. The magnitude of this force and pressure increases with time due to soil densification, resulting in structural problems in the abutments.

The movement of the abutment of integral bridges has two main components, Sliding and Rotating. For many integral abutment bridges, the main component is rotating due to the location of the deck's applied force (at the top) and the high stiffness of soil at the bottom of the abutment. As a result, researchers are more focused on rotating types of wall movement on backfill soil.

Because of the stated reasons, researchers and Manuals propose a new coefficient of lateral earth pressure for designing integral bridges, which is called $K^{*}$, occasionally greater in the upper parts of the wall (Table 2).

In this set of experiments, the variation of the lateral earth pressure with the abutment movement is continuously measured, along with the wall height, using six pressure cells (PCs) for all tests. Then the lateral pressure $\left(\sigma_{\max }^{\prime}\right)$ after 120 cycles is measured by each PC is normalized by the initial vertical stress $\sigma_{\mathrm{v} 0}^{\prime}$ at each particular depth, which would directly result in the 'lateral earth pressure coefficient' $\left(K^{*}\right)$ (Eq. 1).

$$
K^{*}=\frac{\sigma_{h \max }^{\prime}}{\sigma_{\nu 0}^{\prime}}
$$

The horizontal forces measured at the top of the wall represent the produced reaction force of the deck due to expansion and contraction. From this force, the equivalent lateral earth pressure coefficient $\left(\mathrm{K}_{\mathrm{eq}}\right)$ is calculated based on the test result, using

Table 2 Proposed lateral earth pressure coefficient for unreinforced soil behind integral bridge abutments

\begin{tabular}{ll}
\hline Manual & $\boldsymbol{K}^{*}$ Proposed \\
\hline 2003 BA42/96 & $K^{*}=K_{0}+\left(\frac{\delta}{0.03 H}\right)^{0.6} \times K_{p}$ for upper parts \\
Canadian (2006) & $K_{0}$ for bottom \\
Massachusett Bridge (2006) & $K^{*}=33.26\left(\frac{\delta}{H}\right)^{0.44}$ \\
& $K^{*}=0.43+5.7\left(1-e^{\left(\frac{-1908}{H}\right)}\right)$ \\
\hline
\end{tabular}


moment equilibrium about the hinge (Eq. 2) to estimate the total pressure, which is assumed to have a triangular distribution (Fig. 11).

$$
K_{e q}=\frac{6 P}{\gamma H^{2}}
$$

where $\mathrm{P}$ is the lateral load measured by the load cell during the tests, $\mathrm{H}$ is the soil height above the hinge, and $\gamma$ is the unit weight of the dry soil $\left(15.93 \mathrm{kN} / \mathrm{m}^{3}\right)$.

The forces measured by the load cell installed in the actuator resulted in a total pressure distribution that is, in general, $10 \%$ to $25 \%$ low than the resulting horizontal pressures measured by the PC, assuming: (i) a zero pressure at the surface and at the hinge depth and (ii) a linear pressure distribution between the PCs. Such difference might be explained by the existence of some friction between the soil and the sidewalls, resulting in a pressure decrease from the center to the abutment's sides. The Proposed $K_{e q}$. can be used to estimate reaction forces and moments in the bridge deck and abutment.

According to the literature, adding tire rubber to the soil may develop cohesion to the originally cohesionless sand $[15,67]$. In addition, because of the decrease in the reinforced zone's specific density, the vertical stresses also decreased, relative to the values acting on the unreinforced model. Finally, the rubber particles are highly compressible, reducing the pressure applied to the area behind the wall during both active $\left(\sigma_{\text {ha }}^{\prime}\right)$ and passive $\left(\sigma_{\mathrm{hp}}^{\prime}\right)$ states. All these changes cause the stress Mohr circles to distance from the failure envelope, allowing the stress-state in the reinforced zone to become further away from the limit values (Fig. 12).

\section{Results and discussion}

Figure 13 shows the variation of $K_{\text {eq }}$ throughout the 120 cycles of Test 1 , while Fig. 14 shows the normalized displacement of the wall $(\delta / \mathrm{H})$ obtained during loading cycles 1 and 120 of the same Test 1 . As shown in Fig. 13, the maximum value of $K_{\text {eq }}$ increased with the number of cycles, while the minimum values remained constant. The increase in $K_{\text {eq }}$ results from the densification of soil and the formation of a passive zone behind the wall. During the initial cycles, the maximum $\mathrm{K}$ values grow rapidly, but this rate is significantly reduced as the number of cycles increased, suggesting the existence of an

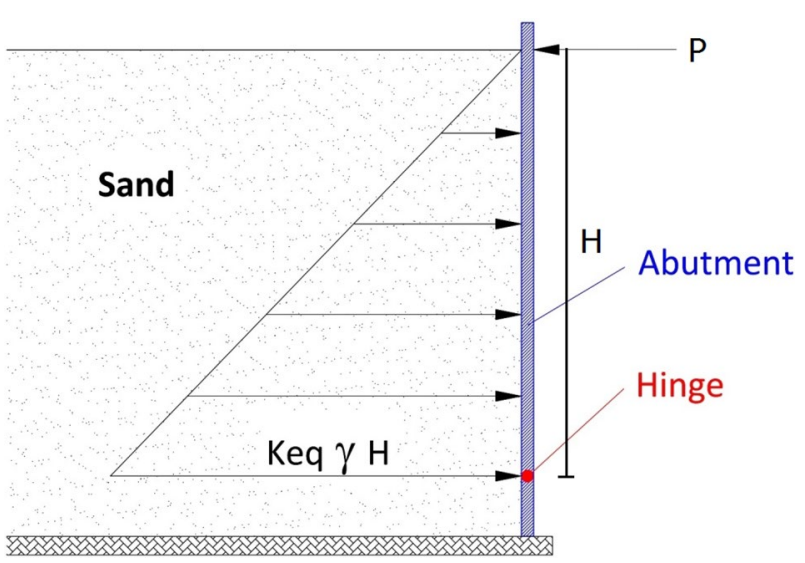

Fig. 11 Distribution (assumed) of the soil pressure required to equilibrate the force $P$ applied on the top 


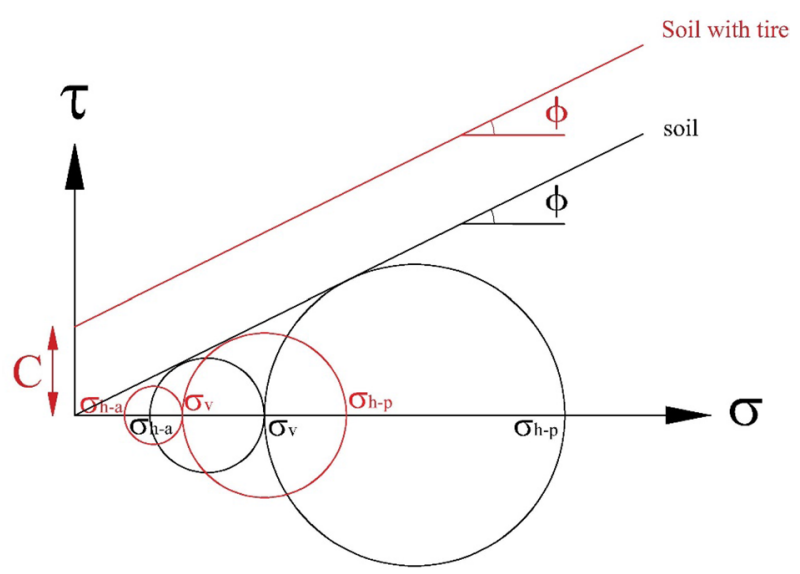

Fig. 12 Stress-state and failure criterion for mixed and unmixed area

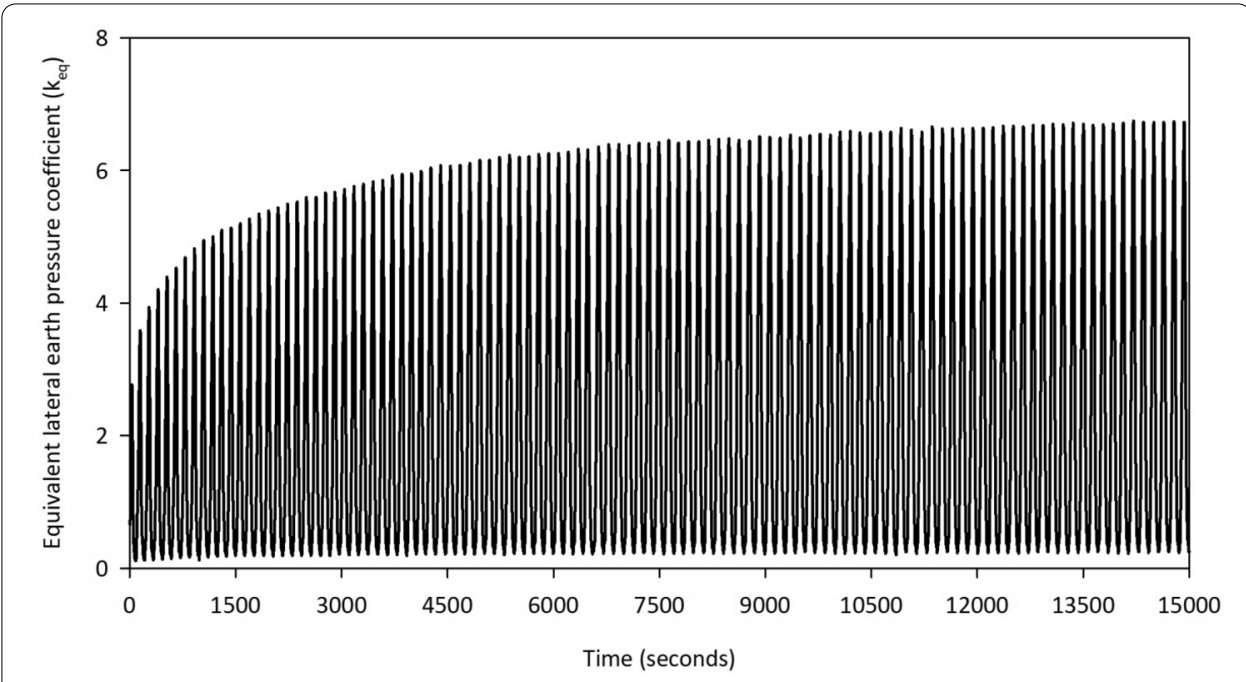

Fig. 13 Variation of the equivalent lateral earth pressure coefficient (K) between cycles 1 and 120 (Test 1 )

asymptotic value. Note that the variation of $\mathrm{K}_{\mathrm{eq}}$ in the passive mode (displacement of the wall toward the backfill) is almost linear, while in the active mode, this variation is clearly nonlinear (Fig. 14). The linear variation of $\mathrm{K}_{\mathrm{eq}}$ in passive mode is the result of the incremental formation of the passive zone behind the wall when the wall pushes the soil. By moving away from the soil in active mode, the pressure behind the wall decreases quickly as a result of sliding in soil, which leads to a nonlinear variation of $\mathrm{K}_{\mathrm{eq}}$.

Figure 15 resumes the evolution of the peak earth coefficient $\left(K_{\text {eq,peak }}\right)$ after 1, 20, $40,60,80,100$, and 120 cycles for the four tests developed. It is clear that the $\mathrm{K}_{\text {eq,peak }}$ increases as the tests progress, especially during the first twenty cycles, after which the increase rate stabilizes. Additionally, the value of $\mathrm{K}_{\text {eq,peak }}$ decreased significantly with the addition of tire-rubber, which can be confirmed by the $\mathrm{K}_{\text {eq,peak }}$ drop after 120 cycles, relatively to the initial value: 55,40 , and $26 \%$, for the tire/area volume ratios of 71,53 , and $28 \%$, respectively. 


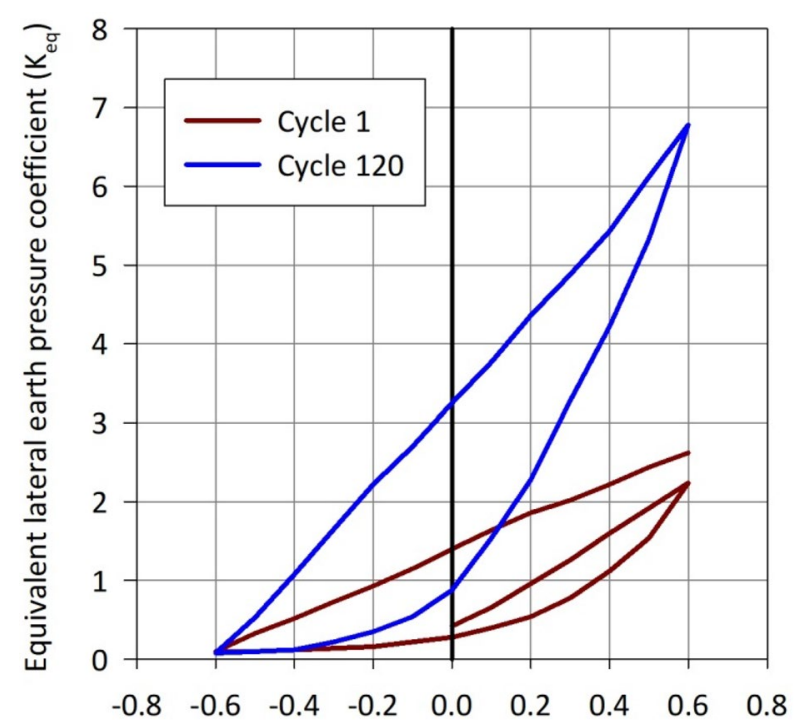

Normalized horizontal displacement at the top $(\delta / \mathrm{H}, \%)$

Fig. 14 Variation of the equivalent lateral earth pressure coefficient (K) during cycles 1 and 120 (Test 1)

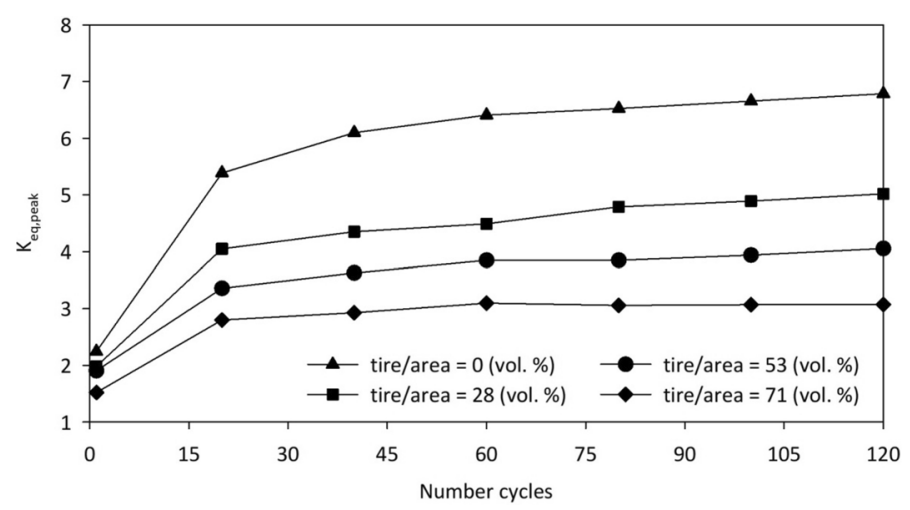

Fig. 15 Variation of $\mathrm{K}_{\text {eq,peak }}$ with cycles during tests

The maximum lateral pressure developed behind the wall after 120 cycles is significantly higher than the initial lateral pressure. As stated before, this increase results from soil densification and the formation of a passive zone behind the wall.

The maximum lateral pressure developed after 120 cycles is obtained for all tests near the top of the abutment. The increasing addition of reinforcement is produced an overall reduction in lateral pressure, indicated by the smaller $\mathrm{K}^{*}$ values (Fig. 16). The variation in $\mathrm{K}^{*}$ below the middle of the wall downwards is very similar for all tests, with the unreinforced test showing an apparent change in slope between the top and bottom half. On the contrary, tire rubber's mixing produced lower differences between the top and bottom parts of the $\mathrm{K}^{*}$ curve. These lower differences might be related to the lower surface settlements obtained with the reinforcement, which reduced the volume of particles settled behind the abutment and mitigated the horizontal stress increase in that area 


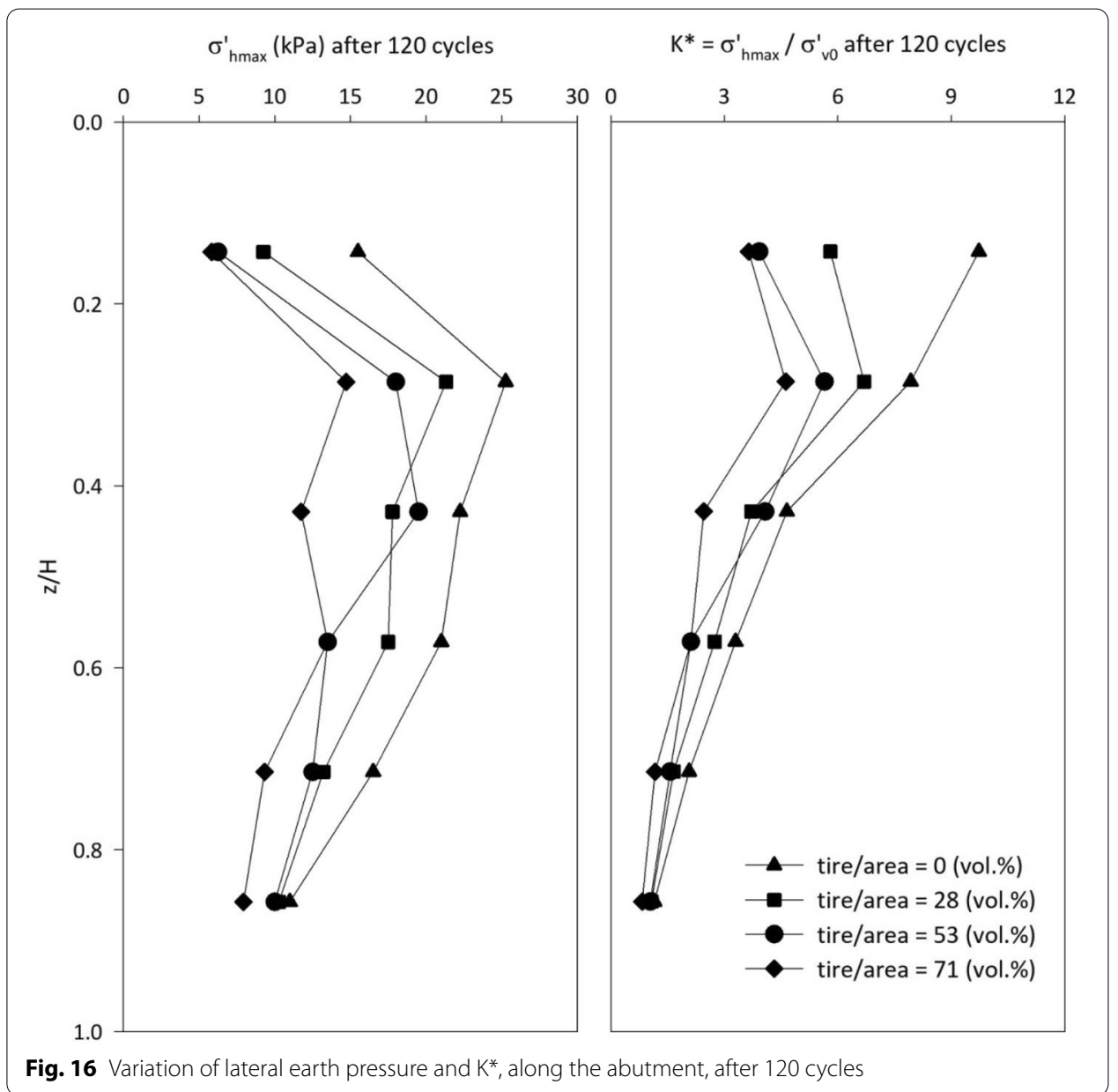

(i.e. the sliding particles produced rigid support for the abutment, enabling this stress increase.

As shown in Fig. 17, there are significant differences between the calculated $\mathrm{K}^{*}$ values at different depths for each model tested. The magnitude of $K^{*}$ decreases with the depth, resulting from the wall's rotating displacement around the hinge. These variations indicate that assuming a constant coefficient for lateral earth pressure for design purposes will lead to significant errors. In all tests after 120 cycles, the $K^{* *}$ value is higher than the $\mathrm{K}_{\text {eq,peak }}$ in the upper half of the abutment, and significantly smaller in the bottom half. This variation suggests that assuming a single value for the lateral earth pressure coefficient may lead to underestimation and overestimation, respectively. The high values of $\mathrm{K}^{*}$ would be problematic, considering the rotational regime controlling the abutment's functioning (i.e. the errors produced on the two halves don't mutually compensate, with the upper half values producing higher moments).

The settlements at the soil surface behind the wall $\left(\mathrm{S}_{\mathrm{bf}}\right)$ after 120 cycles at the distance of $x$ from the wall ( $x$ is normalized by the height of the wall $H$ ) are presented in Fig. 18. A very significant different behavior is measured with the addition of the tire rubber. Simultaneously, the mixed backfill models show similar settlement patterns, except for Test 2 (28\%), which developed a substantial settlement very close to the 


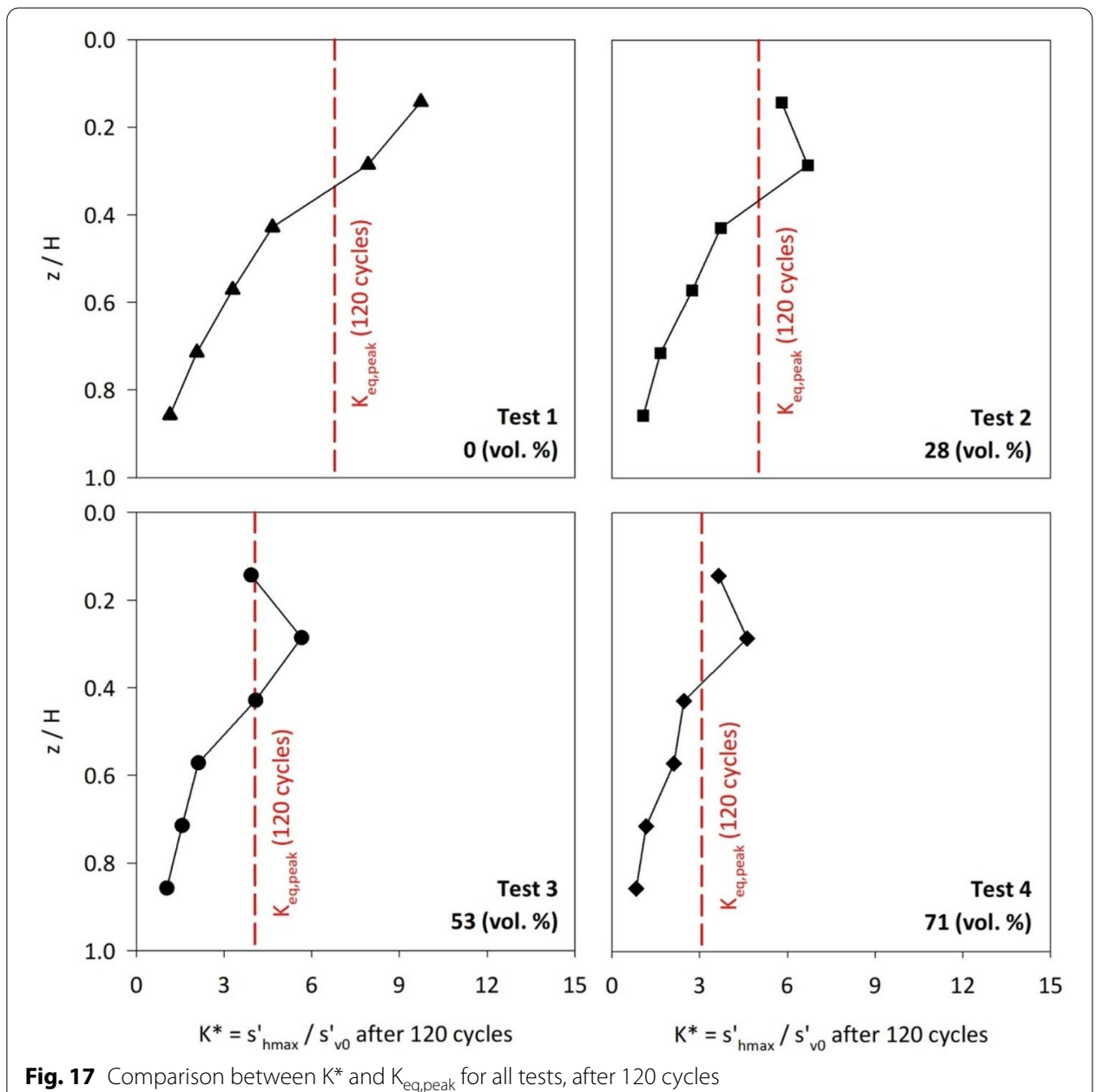

Fig. 17 Comparison between $K^{*}$ and $K_{\text {eq,peak }}$ for all tests, after 120 cycles

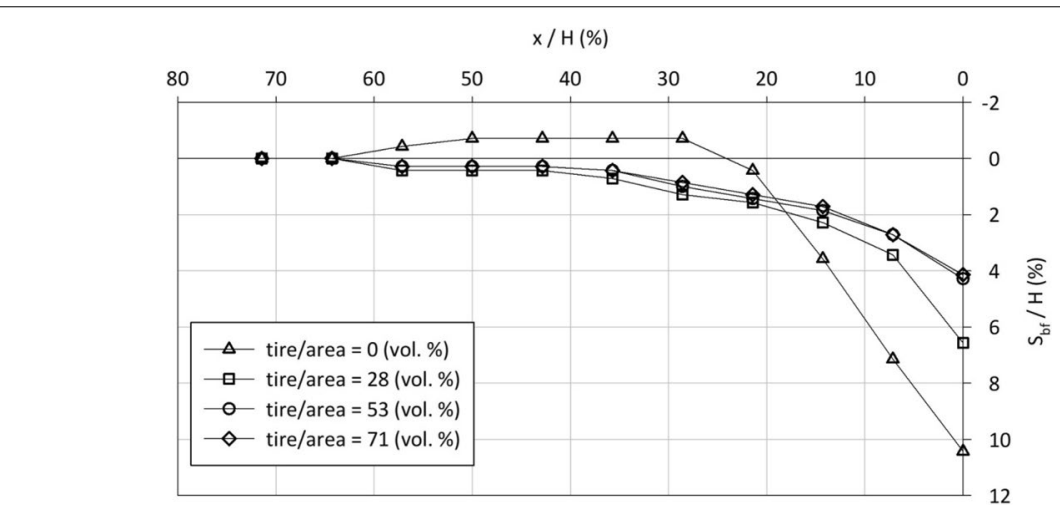

Fig. 18 Settlements near the abutment after 120 cycles

abutment (about 7\% approximately). The tire rubber mixed backfill is able to decrease the surface settlement adjacent to the abutment up to $60 \%$.

According to Tatsuoka et al. [53], increasing lateral earth pressure and large settlements behind the wall (named the 'dual ratchet mechanism') are due to small cyclic 
displacements at the top of the wall. Figure 19a shows an active shear zone, confirmed by several slip lines, developed during Test 1 (no reinforcement), while heaving of the soil surface is also observed behind the active shear zone (passive wedge). In the tests with reinforced backfill, no apparent active shear zone developed behind the wall. Also, the upward movement of the soil (heaving) behind the active shear zone is eliminated. The slip lines inside the reinforced area are now significantly less inclined than those without reinforcement. This is most likely due to the migration of the sand grains to the voids left by the tire-rubber particles during the cycles, resulting in settlement of the soil adjacent to the wall (Fig. 19b). It can thus be suggested that, for practical applications, the tire-rubber and sand layers should be well-compacted to minimize this adverse effect. An alternative solution would be increasing the mixed zone distance from the wall (D). By increasing the mixed zone area, the maximum stresses in the soil behind the mixed zone will decrease due to the compressibility of tire rubbers, which would prevent the formation of minor slips in the soil (Fig. 19b).

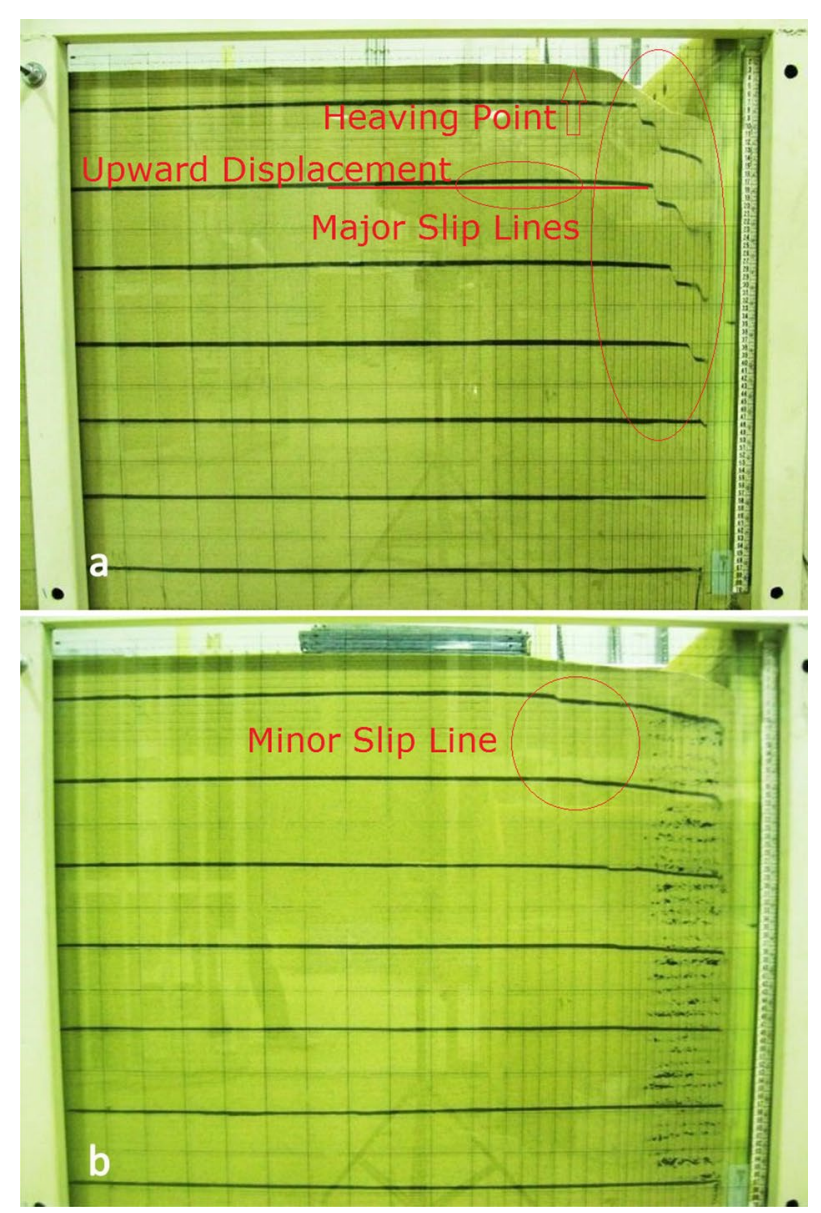

Fig. 19 Development of (a) an active shear zone and slip line during Test 1 ; (b) a significantly less pronounced surface settlement obtained when the reinforcement is applied (tire/area $=71 \%$ ) after 120 cycles 


\section{Conclusions}

This study adds to a growing body of literature on solutions for problems associated with integral bridge backfills. This study shows that using tire rubber would have meaningful long-term benefits on both pressure and settlement behind the integral bridges' abutment. The beneficial impact of mixed tire-sand backfill is a result of tire compressibility. The developed pressures behind the wall decrease up to 59 percent. In addition, despite the higher compressibility of tire rubber in mixed backfill, the settlement behind the wall is decreased significantly. The settlement decrease is due to preventing the dual ratchet mechanism. This study's results and other physical models and field instrumentation for mixed tire-soil backfill could propose a new lateral earth pressure coefficient for integral bridges based on tire content and the area of mixing behind the wall. The specific results of these set of tests indicate that:

- Mixing tire rubber with soil reduced the stress ratio ( $\left.K^{*}\right)$, equivalent peak earth pressure coefficient $\left(\mathrm{K}_{\text {eq,peak }}\right)$, and settlement after 120 cycles significantly.

- The stress ratio $\left(\mathrm{K}^{*}\right)$ is significantly higher in the upper parts of the wall, indicating that assuming a constant value of $K^{*}$ for the wall height will lead to design errors.

- No apparent active shear zone developed, behind the wall, during the reinforced area tests. However, minor slip-lines developed in the adjacent zone, leading to small settlements at the surface.

- In all tests $K^{*}$ is higher than $\mathrm{K}_{\text {eq,peak }}$ after 120 cycles in the upper part of the wall, and smaller in the lower part.

\section{Recommendation for future research}

The results of this study can be corroborated by further studies. The authors recommend additional studies on this topic by conducting full-scale and field experiments. The results of such studies can be compared in terms of dimensionless and normalized parameters presented in this article.

\section{Abbreviations}

IAB: Integral Abutment Bridge; TDA: Tire Derived Aggregate; LVDT: Linear Variable Differential Transformer; PC: Pressure cell; PTFE: Poly Tetra Fluoro Ethylene; GRS: Geosynthetic-Reinforced Structure; EPS: Expanded Poly Styrene.

\section{Nomenclature}

$\mathrm{H}$ : Height of soil behind the wall; D: Width of tire rubber layer; $\delta$ : Wall displacement at its top during one cycle; RD: Relative density (\%); $C_{c}$ : Coefficient of curvature; $C_{u}$ : Coefficient of uniformity; $e_{\text {max }}:$ Maximum void ratio; $e_{\text {min }}$ : Minimum void ratio; Gs: Specific gravity of soil; $V_{\text {tire: }}$ Volume of tire; $V_{\text {mixed }}:$ Volume of mixed zone; $\sigma_{h \max }^{\prime}:$ Maximum lateral pressure measured by Pressure cell; $\sigma_{\mathrm{vv}}^{\prime}$ : Initial vertical stress; $\sigma_{h 0}^{\prime}:$ Initial horizontal stress; $\sigma_{h-p a s s i v e}^{\prime}:$ Major Principal Stress; $\sigma_{h-a c t i v e}^{\prime}$ Minor Principal Stress; $K^{*}$ : Lateral soil coefficient (calculated by dividing Maximum lateral pressure cell to Initial vertical stress); K: Lateral soil coefficient (calculated by load cell force); P: Lateral force measured by load celli; $\gamma$ : S oil moist unit weight $\left(\mathrm{KN} / \mathrm{m}^{3}\right) ; \mathrm{K}_{\text {eq: }}$ : Equivalent lateral soil coefficient in one cycle; $\mathrm{K}_{\text {eq-peak }}$ Peak Equivalent lateral soil coefficient in all cycles; $S_{g}$ : Settlement at soil surface; $z$ : Depth of soil from surface; $x$ : Distance from the wall. 


\section{References}

1. Ahmed I, Lovell C (1993) Rubber soils as lightweight geomaterials. Transp Res Rec (1422). TRB, National Research Council, Washington DC, pp 61-70

2. Al-Qarawi A, Leo C, Liyanapathirana D (2020) Effects of wall movements on performance of integral abutment bridges. Int J Geomech 20(2):04019157

3. Alimohammadi H, Zheng J, Buss A, Schaefer VR, Williams C, Zheng G (2020) Field and simulated rutting behavior of hot mix and warm mix asphalt overlays. Constr Build Mater 265:120366

4. Alimohammadi H, Zheng J, Schaefer VR, Siekmeier J, Velasquez R (2021) Evaluation of geogrid reinforcement of flexible pavement performance: a review of large-scale laboratory studies. Transp Geotech 27:100471

5. Arsoy S, Barker RM, Duncan JM (1999) The behavior of integral abutment bridges. Virginia Transportation Research Council, Charlottesville, VA

6. Bahadori H, Ahmadi A, Ghalandarzadeh A (2007) Effect of silt content on the anisotropic behavior of sand in cyclic loading. In: 4th international confrence on earthquake engineering, Greece.

7. Barker K, Carder D (2001) Performance of an integral bridge over the M1-A1 link road at Branham Crossroads. TRL REPORT 521.

8. Barri K, Jahangiri B, Davami O, Buttlar WG, Alavi AH (2020) Smartphone-based molecular sensing for advanced characterization of asphalt concrete materials. Measurement 151:107212

9. Bloodworth AG, Xu M, Banks JR, Clayton CR (2011) Predicting the earth pressure on integral bridge abutments. J Bridg Eng 17(2):371-381

10. Bolouri Bazaz J, Zadehmohamad M, Hashemi SS (2018) Developing a portable curtain sand pluviator for reconstitution of soil models. Modares Civil Eng J 18(1):231-242

11. Bosscher PJ, Edil TB, Kuraoka S (1997) Design of highway embankments using tire chips. J Geotech Geoenviron Eng 123(4):295-304

12. Brahmachary TK, Rokonuzzaman M (2018) Investigation of random inclusion of bamboo fiber on ordinary soil and its effect CBR value. Int J Geo-Eng 9(1):1-11

13. Cecich V, Gonzales L, Hoisaeter A, Williams J, Reddy K (1996) Use of shredded tires as lightweight backfill material for retaining structures. Waste Manage Res 14(5):433-451

14. Edil TB, Bosscher PJ (1994) Engineering properties of tire chips and soil mixtures. Geotech Test J 17(4):453-464

15. Edinçliler A, Baykal G, Saygılı A (2010) Influence of different processing techniques on the mechanical properties of used tires in embankment construction. Waste Manage 30(6):1073-1080

16. Elyasigorji A, Rezaee M, Ghorbanpoor A (2019) Magnetic corrosion detection in concrete structures. In: International conference on sustainable infrastructure 2019: leading resilient communities through the 21st century, American Society of Civil Engineers Reston, VA.

17. Elyasigorji A, Rezaee M, Ghorbanpoor A (2020) Characterization of corrosion in PS concrete girders by correlation analysis. Structures Congress 2020, American Society of Civil Engineers Reston, VA.

18. England GL, Bush DI, Tsang NC (2000) Integral bridges: a fundamental approach to the time-temperature loading problem, Thomas Telford, London

19. Farahi B, Esfahani MR (2020) Experimental Investigation on the behavior of reinforced concrete beams retrofitted with NSM-SMAVFRP. Amirkabir (Journal of Science and Technology) 51:685-698. https://doi.org/10.22060/ceej.2018.13927.5512

20. Farhangi $\bigvee$, Karakouzian M (2020) Effect of fiber reinforced polymer tubes filled with recycled materials and concrete on structural capacity of pile foundations. Appl Sci 10(5):1554

21. Foroutan M, Hassan MM, Desrosiers N, Rupnow T (2018) Evaluation of the reuse and recycling of drill cuttings in concrete applications. Constr Build Mater 164:400-409

22. Garcia M, Pando MA, Tempest B (2012) Tire derived aggregates as a sustainable recycled material for retaining wall backfills. ICSDC 2011: Integrating Sustainability Practices in the Construction Industry, pp 542-552.

23. Hamedmirjafari B, Bazaz JB, Abrishami S (2019) Experimental investigation of bond stress and creep displacements of GFRP soil nails simulated in a soil box. Int J Civil Eng 17(10):1559-1570

24. Hoppe EJ (2005) Field study of integral backwall with elastic inclusion, Virginia Transportation Research Council.

25. Horvath J (1996) The compressible inclusion function of EPS geofoam: an overview. In: Proceedings of international symposium on eps (expanded poly-styrol) construction method (EPS Tokyo'96).

26. Horvath JS (1997) The compressible inclusion function of EPS geofoam. Geotext Geomembr 15(1-3):77-120

27. Horvath JS (2000) Integral-abutment bridges: problems and innovative solutions using EPS geofoam and other geosynthetics. Res. Rpt. No. CE/GE-00-2 Manhattan College, Civil and Engineering Department, Bronx, NY.

28. Horvath, J. S. (2004). Integral-abutment bridges: a complex soil-structure interaction challenge. Geotechnical engineering for transportation projects. In: Proceedings of geo-trans, Los Angeles, California, USA, ASCE, pp 460-469.

29. Huang F, Shan Y, Chen G, Lin Y, Tabatabai H, Briseghella B (2020) Experiment on Interaction of Abutment, Steel H-Pile and Soil in Integral Abutment Jonitless Bridges (IAJBs) under Low-Cycle Pseudo-Static Displacement Loads. Appl Sci 10(4):1358

30. Humphrey DN, Eaton RA (1993) Tire chips as subgrade insulation: field trial, symposium on recovery and effective reuse of discarded materials and by-products for construction of highway facilities Denver. Colorado, U.S.A

31. Humphrey DN, Manion WP (1992) Properties of tire chips for lightweight fill. Grouting, soil improvement and geosynthetics, ASCE.

32. Humphrey DN, Sandford TC, Cribbs MM, Manion WP (1993) Shear strength and compressibility of tire chips for use as retaining wall backfill. Transp Res Rec (1422). Board, Washington, D.C., pp 29-35

33. Humphrey DN, Whetten N, Weaver J, Recker K, Cosgrove TA (1998) Tire shreds as lightweight fill for embankments and retaining walls. Recycled materials in geotechnical applications, ASCE. 
34. Khaniki AK, Daliri F (2013) Analytical and experimental approaches to obtain the ultimate strength of reinforced earth elements. KSCE J Civ Eng 17(5):1001-1007

35. Kim DS, Kim UJ (2020) Evaluation of passive soil stiffness for the development of integral abutments for railways. J Korean Soc Hazard Mitig 20(4):13-19

36. Karakouzian M, Farhangi V, Farani MR, Joshaghani A, Zadehmohamad M, Ahmadzadeh M. (2021). Mechanical Characteristics of Cement Paste in the Presence of Carbon Nanotubes and Silica Oxide Nanoparticles: An Experimental Study. Materials, 14(6):1347

37. Lee J, Salgado R, Bernal A, Lovell C (1999) Shredded tires and rubber-sand as lightweight backfill. J Geotech Geoenviron Eng 125(2):132-141

38. Lehane B (2011) Lateral soil stiffness adjacent to deep integral bridge abutments. Géotechnique 61(7):593-603

39. Levesque Y, Saeidi A, Rouleau A (2017) An earth pressure coefficient based on the geomechanical and geometric parameters of backfill in a mine stope. Int J Geo-Eng 8(1):27

40. Lock R (2002) Integral bridge abutments. University of Cambridge Department of Engineering, Cambridge

41. Maruri RF, Petro SH (2005) Integral abutments and jointless bridges (IAJB) 2004 survey summary. Integral abutment and jointless bridges (IAJB 2005), Baltimore, Maryland, pp 12-29.

42. MotahariTabari S, Shooshpasha I (2018) Evaluation of coarse-grained mechanical properties using small direct shear test. Int J Geotech Eng 1-13. https://doi.org/10.1080/19386362.2018.1505310

43. Naji M, Firoozi AA, Firoozi AA (2020) A review: study of integral abutment bridge with consideration of soil-structure interaction. Latin Am J Solids Struct 17(2)

44. Özkul ZH, Baykal G (2007) Shear behavior of compacted rubber fiber-clay composite in drained and undrained loading. J Geotech Geoenviron Eng 133(7):767-781

45. Panigrahi B, Pradhan PK (2019) Improvement of bearing capacity of soil by using natural geotextile. Int J Geo-Eng 10(1):9

46. Pourhassan A, Gheni A, ElGawady M (2019) Effect of aggregate size on the retention of conventional and rubberized chip seal

47. Purkar MS, Kute S (2015) Finite element analysis of a concrete-rigid wall retaining a reinforced backfill. Int J Geo-Eng 6(1):14

48. Madhusudhan BR, Boominathan A, Banerjee S (2017) Static and large-strain dynamic properties of sand-rubber tire shred mixtures. J Mater Civil Eng 29(10):04017165

49. Reddy SB, Krishna AM (2015) Recycled tire chips mixed with sand as lightweight backfill material in retaining wall applications: an experimental investigation. Int J Geosynth Ground Eng 1(4):31

50. Rezazadeh Eidgahee D, Haddad A, Naderpour H (2019) Evaluation of shear strength parameters of granulated waste rubber using artificial neural networks and group method of data handling. Scientia Iranica 26(6):3233-3244

51. Sandberg J, Magnino L, Nowak P, Wiechecki M, Thusyanthan I (2020) The integral bridge design concept for the third runway at Heathrow, UK. In: Proceedings of the Institution of Civil Engineers-Bridge Engineering, Thomas Telford Ltd.

52. Sridhar R, Prathap Kumar MT (2018) Effect of number of layers on coir geotextile reinforced sand under cyclic loading. Int J Geo-Eng 9(1):11

53. Tatsuoka F (2008) Recent practice and research of geosynthetic-reinforced earth structures in Japan. J GeoEng 3(3):77-100

54. Tatsuoka F, Hirakawa D, Nojiri M, Aizawa H, Nishikiori H, Soma R, Tateyama M, Watanabe K (2009) A new type of integral bridge comprising geosynthetic-reinforced soil walls. Geosynth Int 16(4):301-326

55. Tatsuoka F, Tateyama M, Koda M, Kojima K-I, Yonezawa T, Shindo Y, Tamai S-I (2016) Research and construction of geosynthetic-reinforced soil integral bridges. Transp Geotech 8:4-25

56. Tatsuoka F, Tateyama M, Koseki J, Yonezawa T (2014) Geosynthetic-reinforced soil structures for railways in Japan. Transp Infrastruct Geotechnol 1(1):3-53

57. Tweedie J, Humphrey D, Sandford T (1998) Tire shreds as lightweight retaining wall backfill: active conditions. J Geotech Geoenviron Eng 124(11):1061-1070

58. Upton RJ, Machan G (1993) Use of shredded tires for lightweight fill. Transp Res Rec (1422).

59. Izadifar M, Mousavi H, Zadehmohamad M, Hosseini SMMM (2021) Evaluating the isolation effect of the soil-rubber mixture (SRM) around buried pipes during ground vibrations, 7th International Conference on Civil Engineering, Architecture and Urban Planning, At Tehran. https://doi.org/10.6084/m9.figshare.14998317

60. Wartman J, Natale MF, Strenk PM (2007) Immediate and time-dependent compression of tire derived aggregate. J Geotech Geoenviron Eng 133(3):245-256

61. Yonezawa T, Yamazaki T, Tateyama M, Tatsuoka F (2014) Design and construction of geosynthetic-reinforced soil structures for Hokkaido high-speed train line. Transp Geotech 1(1):3-20

62. Yoon YW, Heo SB, Kim KS (2008) Geotechnical performance of waste tires for soil reinforcement from chamber tests. Geotext Geomembr 26(1):100-107

63. Zadehmohamad M (2020) Evaluation of cyclic displacement amplitude of integral bridge abutment on backfill soil pressure and settlements. J Transp Res.

64. Zadehmohamad M, Bolouri Bazaz J (2019) Cyclic behaviour of geocell-reinforced backfill behind integral bridge abutment. Int J Geotech Eng 13(5):438-450. https://doi.org/10.1080/19386362.2017.1364882

65. Zaremotekhases F, Idris II, Hassan MM, Mohammad LN, Negulescu II (2020) Effect of sodium alginate fibers encapsulating rejuvenators on the self-healing capability and cracking resistance of asphalt mixtures. J Mater Civ Eng 32(12):04020355

66. Zaremotekhases F, Sadek H, Hassan M, Berryman C, Hossain MI (2021) The use of reclaimed asphalt pavement materials and warm-mix asphalt mixtures in the south-central states: challenges and limitations. Tran-SET 2020, American Society of Civil Engineers Reston, VA, pp 185-194.

67. Zornberg JG, Cabral AR, Viratjandr C (2004) Behaviour of tire shred sand mixtures. Can Geotech J 41(2):227-241

\section{Publisher's Note}

Springer Nature remains neutral with regard to jurisdictional claims in published maps and institutional affiliations. 